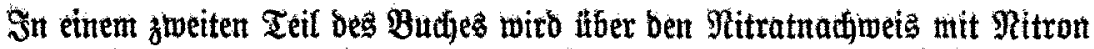

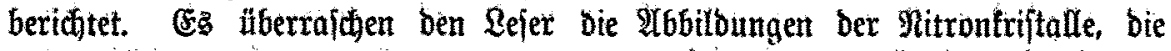
auf optijifem Wege nadigerwieien werben. Die prompte Reattion in Dienge

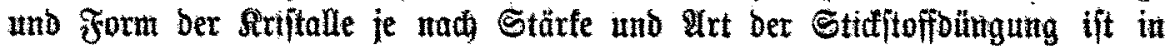
mebreren Serien von Bilbern feitgehalten und fïfyrt ben \&aien in eine igm unbelounte $\mathfrak{B}$ unberwelt ein.

Ces exübrigen fith weitere Sorte: ein lebendiges Bild fann nur bie Rettüre Des Buches vermitteln, baß gelejen zu baben, niemanto bereuen wirb.

Dr. Beorg Senter.

\title{
IV. Kurze Kachrichten.
}

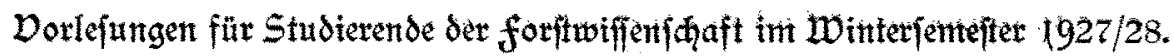

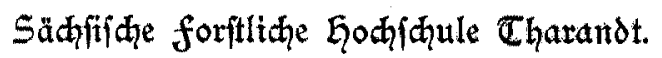

Frofefior Bernbarb, Eanbforfmetfer a. D.: Beurlaubt. Srofefor Dr. Wisticena:

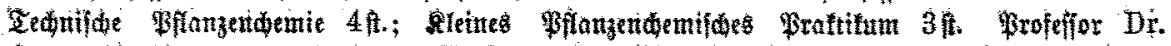

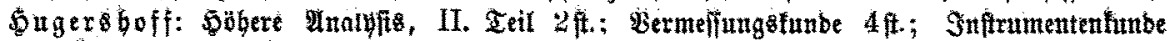

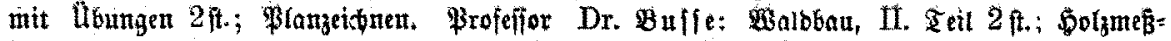

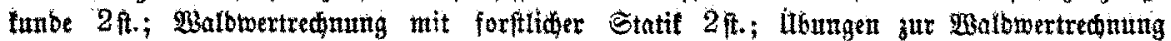
unb forftiden Ctatil 2 f. Frofeffor Dr. Wi th botanifoes Braftitum 2ft.; Banmfrantheiten 2ft. Brofeffor Dr. Wrell: Forftzologie II. Zeil

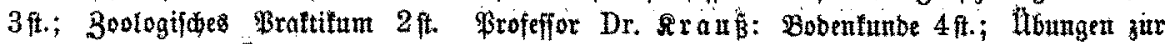

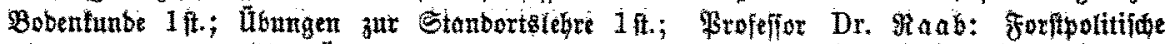

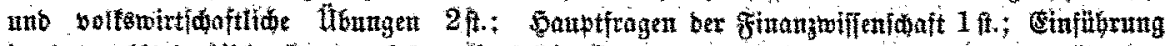

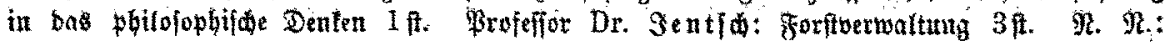

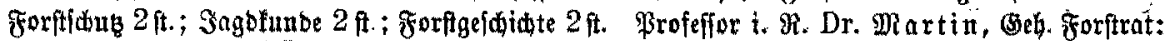

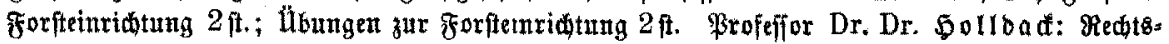

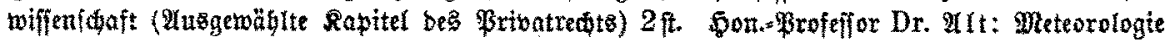

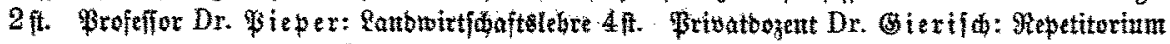

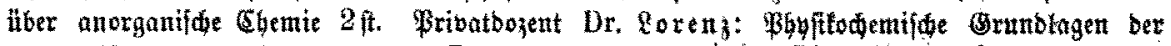

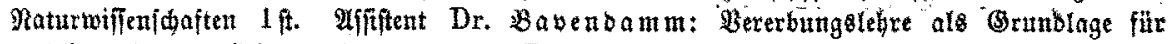

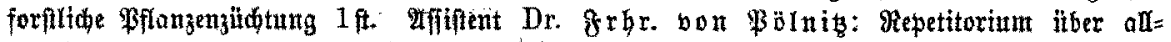

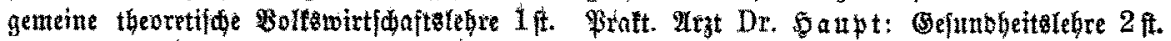
Sportrat Sकimun

Beginn bes Bituterbalbjabres: 15 . Dftober 1927.

Begium ber Borlejungen: 17. Ottober 1927 .

Enbe ber Gorlejungen: Cabe februar 1928.

Qutunbuten: bie 25. Nobember 1927.

\section{Gุoly=Ceḑnifum, Einbed.}

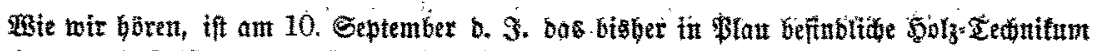

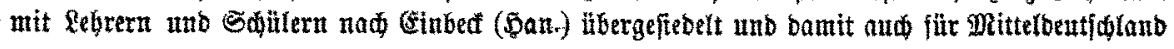

